\title{
Comparison of postoperative quality of life of Limberg flap and Karydakis flap in pilonidal sinus operations
}

\author{
Sabahattin Destek (ID), Hüseyin Kazım Bektaşoğlu( (ID), Enver Kunduz (ID), Merve Nil Akyüz²(ID) \\ ${ }^{1}$ Department of General Surgery, Bezmialem Vakif University School of Medicine, Istanbul, Turkey \\ 2 Department of Internship, Bezmialem Vakif University School of Medicine, Istanbul, Turkey
}

\begin{abstract}
Objective: Pilonidal sinus disease (PSD), most commonly seen in young men, is a chronic disease resulting from the pilosebaceous in the sacrococcygeal region. There is still no standardization in surgical treatment. In this study, the effectiveness, follow up outcomes and quality of life level were compared between Karydakis flap (KF) and Limberg flap (LF) operations.

Material and Methods: Among the patients who had undergone PSD surgery in our clinic between 2015 and 2016, those who could be reached and who received KF $(n=53)$ and LF $(n=51)$ operations were included into the study. Clinical data of these patients were retrospectively evaluated. Postoperative satisfaction levels of the patients were determined with Cardiff wound healing survey questions and visual analog scale.

Results: Mean operational time was 54 (44-75) minutes in the LF group and 45 (35-60) minutes in the KF group, and it was statistically significant ( $p=0.001$ ). Mean time to return to work was 14.3 (9-28) days in the LF group and 17.6 (10-30) days in the CF group and was statistically significant ( $p=0.001)$. The rates of complications and recurrence were lower in the LF group although the difference was not statistically significant between the groups ( $p>0.05$ ). Mean $p s y-$ chosocial assessment score was 70.3 (57.5-88.7) in the KF group and 73.4 (53.5-87.5) in the LF group and the difference was statistically significant ( $p=0.001$ ).

Conclusion: LF was a more reliable and preferable method compared to KF because of earlier return-to-work, lower rate of recurrence at long term follow up, and higher psychosocial satisfaction.
\end{abstract}

Keywords: Pilonidal sinus disease, Karydakis flap, Limberg flap, quality of life

Cite this article as: Destek S, Bektaşoğlu HK, Kunduz $E_{i}$ Akyüz MN. Comparison of postoperative quality of life of Limberg flap and Karydakis flap in pilonidal sinus operations. Turk J Surg 2020; 36 (1): 59-64.

\section{Corresponding Author} Sabahattin Destek

E-mail: sebahattindestek@yahoo.com

Received: 31.07.2019

Accepted: 06.11.2019

Available Online Date: 18.03 .2020

O Copyright 2020 by Turkish Surgical Society Available online at www.turkjsurg.com

DOI: $10.5578 /$ turkjsurg.4598

\section{INTRODUCTION}

Pilonidal sinus disease (PSD) which was described for the first time by Herbert Mayo in 1833 , is seen in $0.7 \%$ of the world population (1). Of all PSD cases, $97.8 \%$ are observed in the sacrococcygeal region, and $2.2 \%$ in extra sacrococcygeal regions such as fingers, umbilicus and neck $(1,2)$. PSD has been mostly defined in young men (1). Both environmental and genetic factors are thought to play a role in the etiology of the disease (3). The major pathogenic cause for PSD is local and repeating minor trauma in hairy areas $(1,2)$. PSD is chronic, but occasionally becomes abscessed with acute exacerbations (3).

Many conservative and surgical methods are used in the treatment of PSD (3). Numerous surgical methods including sinus excision and primary closure, cryosurgery, marsupialization, Limberg flap (LF), Karydakis flap (KF), V-Y flap, and Z-plasty are used for the treatment of PSD $(1,4)$. However, current recurrence rates are high at $5-22 \%$ $(3,4)$. Debates about the ideal treatment methods are continuing since recurrence rates are high, and various advantages and disadvantages of treatment methods, and novel techniques are being continuously developed (4). In this study, we aimed to evaluate the outcomes of KF and LF methods used for PSD to assess postoperative quality of life and to determine which method is superior by comparisons.

\section{MATERIAL and METHODS}

\section{Study Groups}

Patients who had undergone sacrococcygeal PSD in our clinic between 2015 and 2016 were evaluated for relevance of the time period to better determine 
follow-up process and development of recurrences. This study was approved by the local ethics committee of the university with 18/09/2018 dated and 17/722 numbered decision. Patients who were regularly followed-up in the postoperative period for at least two years and who could be reached via phone were included into the study. KF ( $n=53)$ and LF ( $n=51)$ groups were randomly formed with these patients. Clinical files of the patients were retrospectively screened, and demographic features, primary or secondary (recurrence) status, the surgical technique performed, healing duration, complication status and recurrence rates of these patients were evaluated.

A questionnaire was applied postoperatively in order to compare life comfort of all the patients. Cardiff wound healing survey developed by the Wales University Medical Faculty, Wound Healing Research Department was used as the questionnaire (5). Overall quality of life score, postoperative satisfaction score, psychosocial assessment score, and physical assessment score of the patients were determined using visual analog scale (VAS) with the answers given to this questionnaire (6). Patients were asked to choose the level corresponding to their own status on a line divided as $100 \mathrm{~mm}$ for each score to be determined with VAS.

\section{Statistical Analysis}

Data obtained from the study was statistically analyzed using SPSS (Statistical Package for Social Sciences) for Windows version 23.0 (SPSS Inc. Chicago, IL, USA). Power analysis was used to determine the number of patients. Data were evaluated with a biostatistics specialist at 95\% confidence interval and $p<0.05$ significance level. According to data distribution, normally distributed variables were compared between the two groups using Student's t test, and non-normally distributed variables using Mann-Whitney $U$ test, while categorical variables were compared using Chi-square method. Comparison of the Cardiff wound healing satisfaction survey scores between the two groups was carried out with Mann-Whitney U tests.

\section{RESULTS}

In the KF group, age range was found as 17-49 (mean 29.1) years. Of the patients in the KF group, $81.1 \%(n=43)$ were males and $18.9 \%(n=10)$ were females. Of these patients, $75.5 \%(n=$ 40) were primary and $24.5 \%(n=13)$ were secondary (recurrence) cases. Duration of symptoms was determined as 2-36 (mean 8) months in patients who usually presented with sensation of sting, swelling and/or discharge in the sacrococcygeal region. Mean operational time was measured as 35-60 (mean 45) minutes, and length of hospital stay as 1-5 (mean 2.5) days. All patients were drained, with a duration between 3-7 (mean 4.2) days. The duration of healing and return-to-work was 10-30 (mean 17.6) days (Figure 1).

In the LF group, age range was found as 15-57 (mean 28.3) years. Of the patients in the LF group, $76.5 \%(n=39)$ were males and $23.5 \%(n=12)$ were females. Of these patients, $82.4 \%(n=42)$ were primary and $17.6 \%(n=9)$ secondary (recurrence) cases. Duration of symptoms was determined as 1-33 (mean 6) months. Operational time was measured as 44-75 (mean 54) minutes, and this was significantly longer compared to the KF group ( $p=$ 0.001). Length of hospital stay was found as 1-5 (mean 2.3) days. Again, all patients in this group were drained with a duration of 3-8 (mean 4.6) days. Duration of healing and return-to-work was found as 9-28 (mean 14.2) days, which was statistically shorter compared to the KF group ( $p=0.001)$ (Figure 2$)$. No statistically significant difference was found between the groups in terms of other parameters ( $p>0.05)$ (Table 1).

In the KF group, 4 (7.5\%) patients developed seroma in the wound site, 1 (1.9\%) hematoma in the wound site, 2 (3.8\%) wound site infection, and 2 (3.8\%) dehiscence of incision when skin sutures were removed. During follow up, recurrence was found as $7.5 \%(n=4)$ in the KF group with a mean duration to recurrence as 20 (16-22) months.

In the LF group, 3 (5.9\%) developed seroma in the wound site, 1 (2\%) hematoma in the wound site, 1 (2\%) wound site infection

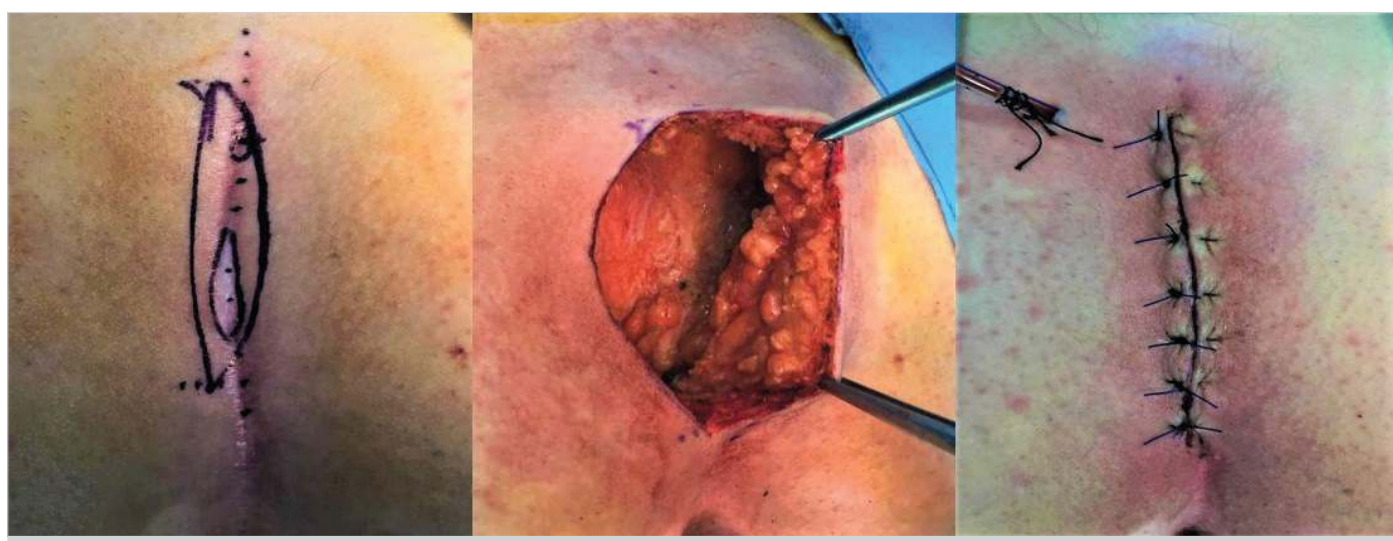

Figure 1. Karydakis flap application in pilonidal sinus disease (preoperative appearance, flap preparation, postoperative appearance). 

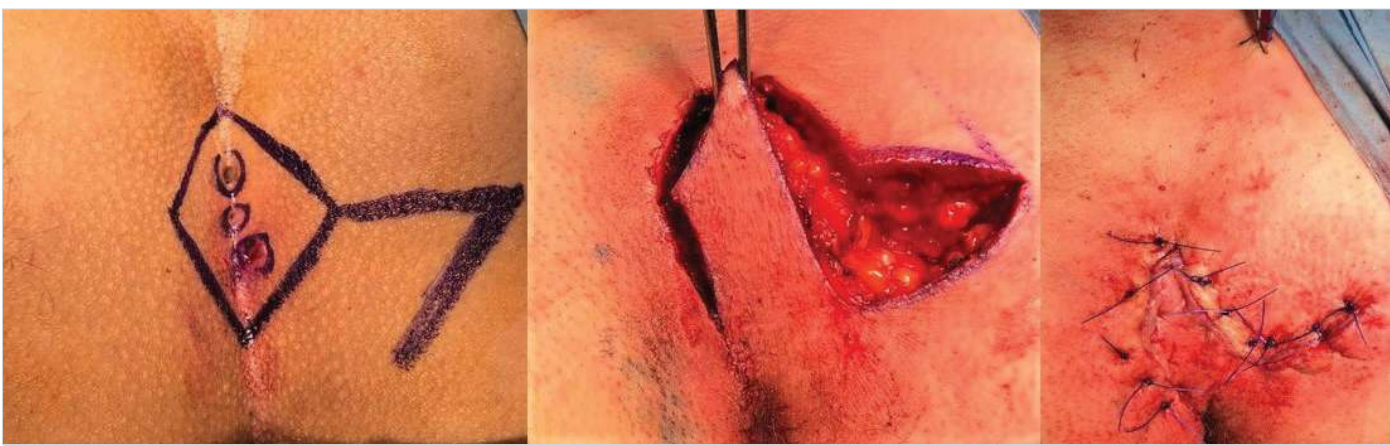

Figure 2. Limberg flap application in pilonidal sinus disease (preoperative appearance, flap preparation, postoperative appearance).

Table 1. Demographic data and clinical results of Karydakis flap and Limberg flap groups

\begin{tabular}{|c|c|c|c|}
\hline Demographic and clinical features & Karydakis flap group $(n=53)$ & Limberg flap group $(n=51)$ & $p$ \\
\hline Age (years) & 17-49 (mean 29.1) & 15-57 (mean 28.3) & $0.613^{\mathrm{a}}$ \\
\hline Gender (female/male) & $10 / 43$ & $12 / 39$ & $0.560^{b}$ \\
\hline Primary/secondary (recurrence) status & $40 / 13$ & $42 / 9$ & $0.390^{b}$ \\
\hline Symptom duration (month) & 2-36 (mean 8) & 1-33 (mean 6) & $0.527^{c}$ \\
\hline Operational time (minutes) & $35-60($ mean 45$)$ & 44-75 (mean 54) & $0.001^{c}$ \\
\hline Duration of hospitalization (days) & 1-5 (mean 2.5) & 1-5 (mean 2.3) & $0.574^{c}$ \\
\hline Duration of drainage (days) & 3-7 (mean.4.2) & 3-8 (mean 4.6) & $0.50^{c}$ \\
\hline Duration of return-to-work (days) & 10-30 (mean 17.6) & 9-28 (mean 14.3) & $0.001^{c}$ \\
\hline
\end{tabular}

Table 2. Complications and recurrence in Karydakis flap and Limberg flap groups

\begin{tabular}{|l|c|c|c|}
\hline Complications/recurrence & Karydakis flap group (n= 53) & Limberg flap group (n= 51) & p \\
\hline Seroma in the wound site & $4(7.5 \%)$ & $3(5.9)$ & $0.314^{\mathrm{a}}$ \\
\hline Hematoma in the wound site & $1(1.9 \%)$ & $1(2 \%)$ & $0.546^{\mathrm{a}}$ \\
\hline Wound site infection & $2(3.8 \%)$ & $1(2 \%)$ & $0.491^{\mathrm{a}}$ \\
\hline Suture dehiscence & $2(3.8 \%)$ & $1(2 \%)$ & $0.491^{\mathrm{a}}$ \\
\hline Recurrence & $4(7.5 \%)$ & $3(5.9 \%)$ & $0.314^{\mathrm{a}}$ \\
\hline Time to recurrence (months) & $16-22$ (mean 20) & $\mathbf{0 . 0 0 1 ^ { \mathbf { b } }}$ \\
\hline $\begin{array}{l}\text { a } \text { Chi-square analysis } \\
{ }^{\mathrm{b}} \text { Mann-Whitney U test. }\end{array}$ & & & \\
\hline
\end{tabular}

and 1 (2\%) dehiscence of incision when skin sutures were removed. During follow up, recurrence was found as $5.9 \%(n=3)$ in the LF group with a mean duration to recurrence as 22 (15-24) months. Duration to recurrence was statistically shorter in the KF group compared to the LF group ( $p=0.001)$. No statistically significant difference was found between the groups in terms of other parameters ( $p>0.05$ ) (Table 2).

In the KF group, overall life satisfaction score was found as 5-9 (mean 6.5), postoperative satisfaction score as 4-9 (mean 6.7), psychosocial assessment score as 54.1-78.9 (mean 68.3), and physical assessment score as 57.5-88.7 (mean 70.3). In the IF group, overall life satisfaction score was found as 5-8 (mean 6.7), postoperative satisfaction score as 4-8 (mean 6.3), psychosocial assessment score as 53.5-87.5 (mean 73.4), and physical assessment score as 42.7-95.8 (mean 67.9). Psychosocial assessment score was significantly higher in the LF group compared to KF group ( $p=0.001$ ). No statistically significant difference was found between the groups in terms of other parameters ( $p>0.05$ ) (Table 3). 
Table 3. Cardiff wound healing scores in Karydakis flap and Limberg flap groups

\begin{tabular}{|l|c|c|c|}
\hline Cardiff wound healing survey questions & Karydakis flap group $(\mathbf{n = 5 3 )}$ & Limberg flap group $(\mathbf{n}=\mathbf{5 1})$ & $\mathbf{p}$ \\
\hline Overall life satisfaction & $5-9($ mean 6.5) & $4-9($ mean 6.7) & $0.484^{\mathrm{a}}$ \\
\hline Postoperative satisfaction & $4-9($ mean 6.7) & $4-8($ mean 6.3) & $0.258^{\mathrm{a}}$ \\
\hline Psychosocial assessment & $54.1-78.9($ mean 68.3) & $53.5-87.5($ mean 73.4) & $\mathbf{0 . 0 0 1}^{\text {a }}$ \\
\hline Physical assessment & $57.5-88.7$ (mean 70.3) & $42.7-95.3($ mean 67.9) & $0.261^{\text {a }}$ \\
\hline${ }^{a}$ Mann-Whitney U test. & &
\end{tabular}

\section{DISCUSSION}

PSD is a chronic disease seen especially in young men and in the navicular area in the intergluteal region, which involves the natal cleft. In general, the incidence of PSD is reported as 26/100.000 (7). PSD reaches the highest incidence between 15-30 years of life and is seen 3-4 times higher in men than in women $(1,7)$. The disease is more common in the Middle East and Caucasians $(1,2)$. In Turkey, the disease is generally seen by 6.6\%. PSD is seen 16 times more common in men, with being most frequently found in 19-20 years of age in Turkey (8).

The etiology of this disease is still not fully understood (8). Nevertheless, the disease is thought to be associated with hormonal changes that lead to hair obstruction and development of hair follicles in the pilosebaceous glands in the sacrococcygeal region $(1,2)$. The known major risk factors include obesity (BMI $>25 \mathrm{~kg} / \mathrm{m}^{2}$ ), local trauma, prolonged sitting, deep natal clefts in the navicular area, hormonal disturbances such as increased total testosterone and prolactin, poor hygienic behaviours, hairy body type, and positive family history (8-10). In several studies, family history has been reported in $17-71.7 \%$ of the patients $(1,8,9)$. Recent studies have reported that the disease was most commonly seen in the profession requiring prolonged sitting and students $(70.1 \%)(8,9)$.

Although various studies have been conducted for the classification of disease severity and treatment choice, no an ideal system could still be established (11). Among the current classifications, the most common is the classification by Dr. Tezel (12). Common complaints frequently seen in chronically symptomatic patients are discharge (100\%), pain (61\%), swelling (43\%) and bleeding $(5 \%)(9,10)$. Clinical picture can be asymptomatic in $4.5 \%$ of the patients (8). Acute abscess requiring surgical drainage is developed in $9-28 \%$ of the patients $(9,10)$. Chronic cases manifest with discharge by development of complex sinus and fistula tracts $(2,9)$. Duration of the disease is between 1 and 84 months, with a mean duration of 14.7 months $(9,10)$.

In differential diagnosis; sebaceous cysts, lipoma, fibroma, fibrous dysplasia, epidermoid cysts, dermoid cysts, Hidradenitis suppurativa, and Ewing's sarcoma should be taken into account $(1,3)$. Repeating PSD can cause fistulas to the anal canal, lumbar osteomyelitis, epidural abscess, and malignant transformations such as rarely developed squamous cell carcinoma (13-15).
Although numerous conservative and surgical treatment methods have been described for PSD, the rates of surgery related complications and recurrences remain high, and the search for an ideal treatment method is continuing $(1,2)$. The goal of treatment is to provide good wound healing, short duration of hospitalization, less complications, low recurrence rate, and high patient satisfaction $(2,16)$. The principle in PSD surgery is to remove the pilonidal sinus tissue and epithelium-lined fistulas. Wound closure is performed using mid-line and extramid-line techniques including primary closure, Z-plasty, VY advancement, Karydakis transposition, and Limbert rotation flap. Recently, extramid-line closure or flap techniques are more often preferred because of the lower recurrence rates compared to other methods $(2,16)$.

Early period complications of surgical treatment include infection, hematoma, and seroma, dehiscence, while late period complications involve numbness, pain, itching, cosmetic problems and recurrence. Different rates of complications and recurrences have been reported in different series. A conservative approach is suitable for asymptomatic patients (16). Studies have reported recurrence rates after a 5-year follow up as 40.2\% in incision and drainage, $13.1 \%$ in excision and secondary healing, 16.8\% in excision and primary closure, 15.6\% in Bascom technique, $1.9 \%$ in KF method, and 5.2\% in LF methods $(2,16)$. Among the minimally invasive surgeries, recurrence has developed by $6.3 \%$ in endoscopic pilonidal sinus treatment and $40.4 \%$ in sinus phenolization (16). Scar tissue remaining in the cleft after primary closure is shown as the most important cause of recurrence. On the other hand, incomplete resection, postoperative dead areas, over flap tension and local ischemia, chronic inflammation, trauma, and secondary infections also increase the risk of recurrence (1-3).

Flap methods providing removal of the intergluteal sulcus enable excision of more pilonidal sinus tissue and decrease the tension in the incision site $(16,17)$. Although currently the most commonly performed extra midline closure methods are KF and LF, still an extra midline closure flap technique that would be most practical could not be determined $(17,18)$.

Studies comparing KF and LF methods have reported different results. Looking to various meta-analyses involving randomized controlled studies comparing KF and LF methods, rates of se- 
roma have been found significantly higher with KF technique. No significant difference was found in terms of recurrence rates and other variables (19-22).

In our study, operational time was statistically shorter in the KF group, and duration of return-to work was statistically shorter in the LF group. The rates of complications and recurrence were lower in LF group, but the differences were not statistically significant. Duration to recurrence was significantly shorter in the KF group. Psychosocial satisfaction score was significantly higher in the LF group compared to the KF group.

\section{CONCLUSION}

In conclusion, both KF and LF methods have their own advantages and disadvantages. However, it was seen in our study that LF is a more reliable and preferable method compared to the KF method because of earlier return-to-work and lower rate of recurrence. Patients undergoing LF are psychosocially more satisfied in terms of life comfort.

Ethics Committee Approval: Authors declared that the research was conducted according to the principles of the World Medical Association Declaration of Helsinki "Ethical Principles for Medical Research Involving Human Subjects" (amended in October 2013). This study was approved by the local ethics committee of Bezmialem University with 18/09/2018 dated and 17/722 numbered decision.

Informed Consent: Written informed consent was obtained from patients who participated in this study.

Peer-review: Externally peer-reviewed.

Author Contributions: Concept - S.D., M.N.A; Design - S.D., M.N.A; Supervision - E.K., H.K.B; Resource - S.D., H.K.B.; Materials - S.D., H.K.B.; Data Collection and/or Processing - S.D., E.K., H.K.B., M.N.A.; Analysis and/or Interpretation - S.D., E.K.; Literature Review - S.D., M.N.A.; Writing Manuscript - S.D., H.K.B.; Critical Reviews - S.D., E.K., H.K.B.

Conflict of Interest: The author declares that she has no conflict of interest.

Financial Disclosure: The authors declared that this study has received no financial support.

\section{REFERENCES}

1. Shabbir J, Chaudhary BN, Britton DC. Management of sacrococcygeal pilonidal sinus disease: a snapshot of current practice. Int I Colorectal Dis 2011;26(12):619-20. [CrossRef]

2. Çiftci F, Abdurrahman I. A different disease: extrasacrococcygeal piIonidal sinuses etiopathogenesis. Int J Clin Exp Med 2015;8:11567-71. [CrossRef]

3. Johnson EK. Expert commentary on pilonidal disease: management and definitive treatment. Dis Colon Rectum 2018;61:777-9. [CrossRef]

4. Varnalidis I, loannidis O, Paraskevas G, Papapostolou D, Malakozis SG, Gatzos $S$, et al. Pilonidal sinus: a comparative study of treatment methods. J Med Life 2014;7:27-30. [CrossRef]
5. Price P. Harding K. Cardiff wound impact schedule: the development of a condition-specific questionnaire to assess health-related quality of life in patients with chronic wounds of the lower limb. Int Wound J 2004;1:107. [CrossRef]

6. DeLoach LJ, Higgins MS, Caplan, AB, StiffJL. Thevisual analog scale in the immediate postoperative period: Intrasubject variability and correlation with a numeric scale. Anesth Analg 1998;86:102-6. [CrossRef]

7. Sondenaa K, Andersen E, Nesvik I, Soreide JA. Patient characteristics and symptoms in chronic pilonidal sinus disease. Int I Colorectal Dis 1995;10:39-42. [CrossRef]

8. Duman K, Gırgin M, Harlak A. Prevalence of sacrococcygeal pilonidal disease in Turkey. Asian J Surg 2017:40:434-7. [CrossRef]

9. HarlakA, Mentes O, Kilic S, Coskun K, Duman K, Yilmaz F. Sacrococcygeal pilonidal disease: analysis of previously proposed risk factors. Clinics (Sao Paulo) 2010;65:125-31. [CrossRef]

10. Bolandparvaz S, Moghadam Dizaj P, Salahi R, Paydar S, Bananzadeh $M$, Abbasi HR, et al. Evaluation of the risk factors of pilonidalsinus: a single center experience. Turk J Gastroenterol 2012;23:535-7. [CrossRef]

11. Beal EM, Lee MJ, Hind D, Wysocki AP, Yang F, Brown SR. A systematic review of classification systems for pilonidal sinus. Tech Coloproctol 2019. [CrossRef]

12. Tezel E. A new classification according to navicular area concept for sacrococcygeal pilonidal disease. Colorectal Dis 2007;9:575-6. [CrossRef]

13. Accarpio G, Davini MD, Fazio A, Senussi OH, Yakubovich A. Pilonidal sinus with an anal canal fistula. Report of a case. Dis Colon Rectum 1988;31:965-7. [CrossRef]

14. Gordon KJ, Hunt TM. Osteomyelitis as a complication of a pilonidalsinus. Int J Colorectal Dis 2016;31:155-6. [CrossRef]

15. Esposito F, Lauro M, Tirone LP, Festa RM, Peluso G, Mazzoni G, et al. Squamous cell carcinoma and pilonidal cyst disease. Ann Ital Chir 2015;86(ePub). [CrossRef]

16. Harries RL, Alqallaf A, Torkington J, Harding KG. Management of sacrococcygeal pilonidal sinus disease. Int Wound J 2019;16:370-8. [CrossRef]

17. Petersen S. Pilonidal sinus disease; what is the best treatment option? Zentralbl Chir 2019. [CrossRef]

18. Alvandipour M, Zamani MS, Ghorbani M, Charati JY, Karami MY. Comparison of Limberg flap and Karydakis flap surgery for the treatment of patients with pilonidal sinus disease: a single-blinded parallel randomized study. Ann Coloproctol 2019. [CrossRef]

19. Ates M, Dirican A, Sarac M, Aslan A, Colak C. Short and long-term results of the Karydakis flap versus the Limberg flap for treating pilonidal sinus disease: a prospective randomized study. Am J Surg 2011;202:568-73. [CrossRef]

20. Prassas D, Rolfs TM, Schumacher FJ, Krieg A. Karydakis flap reconstruction versus Limberg flap transposition for pilonidal sinus disease: a meta-analysis of randomized controlled trials. Langenbecks Arch Surg 2018:403:547-54. [CrossRef]

21. Sahebally SM, McMahon G, Walsh SR, Burke JP. Classical Limberg versus classical Karydakis flaps for pilonidal disease - an updated systematic review and meta-analysis of randomized controlled trials. Surgeon 2018. [CrossRef]

22. Gavriilidis P, Bota E. Limberg flap versus Karydakis flap for treating pilonidal sinus disease: a systematic review and meta-analysis. Can J Surg 2019;62:131-8. [CrossRef] 


\title{
ORIJINAL ÇALIŞMA-ÖZET
}

Turk J Surg 2020; 36 (1): 59-64

\section{Pilonidal sinüs ameliyatlarında Limberg flap ve Karydakis flap yöntemlerinin ameliyat sonrası hayat kalitesi açısından karşılaştırılması}

\author{
Sabahattin Destek ${ }^{1}$, Hüseyin Kazım Bektaşoğlu ${ }^{1}$, Enver Kunduz ${ }^{1}$, Merve Nil Akyüz ${ }^{2}$ \\ 1 Bezmialem Vakıf Üniversitesi Tıp Fakültesi, Genel Cerrahi Anabilim Dalı, İstanbul, Türkiye \\ ${ }^{2}$ Bezmialem Vakıf Üniversitesi Tıp Fakültesi, Staj Bölümü, İstanbul, Türkiye
}

\section{ÖZET}

Giriş ve Amaç: Pilonidal sinüs hastalığı (PSH) sakrokoksigeal bölgede bulunan ve çoğunlukla genç erkeklerde görülen pilosebase kaynaklı kronik bir hastalıktır. Cerrahi tedavisinde hala standardizasyon yoktur. Bu çalışmada, kliniğimizde yapılan Karydakis flep (KF) ve Limberg flep (LF) ameliyatlarının etkinlik, takip sonuçları ve yaşam kalitesi karşılaştırılmıştır.

Gereç ve Yöntem: 2015-2016 yılları arasında kliniğimizde PSH tanısı ile ameliyat edilen hastalar arasından iletişim kurulabilen KF ( $n=53$ ) ve LF $(n=51)$ yapılan hastalar çalışmaya alındı. Bu hastaların klinik verileri retrospektif olarak değerlendirildi. Hastaların ameliyat sonrası memnuniyet düzeyleri, Cardiff yara iyileşme anket soruları ve görsel analog skalası ile belirlendi.

Bulgular: Çalışmamızda ortalama operasyon süresi LF grubunda 54 (44-75) dakika, KF grubunda 45 (35-60) dakika idi ve istatistiksel olarak anlamlıydı ( $p=0,001$ ). İşe geri dönme süresi LF grubunda 14,3 (9-28) gün, KF grubunda 17,6 (10-30) gündü ve yine istatistiksel olarak anlamlıydı ( $p=$ 0,001). Her iki grup arasındaki istatistiksel olarak anlamlı fark olmasa da, komplikasyon ve nüks oranı LF grubunda düşüktü ( $p>0,05)$. Ortalama psikososyal değerlendirme skoru KF grubunda $70,3(57,5-88,7)$, LF grubunda $73,4(53,5-87,5)$ idi ve istatistiksel olarak anlamlıdı $(p=0,001)$.

Sonuç: LF, işe geri dönüş süresi, uzun süreli takiplerde daha düşük nüks oranları ve daha yüksek psikososyal memnuniyet nedeniyle KF yöntemine kıyasla daha güvenilir ve tercih edilen bir yöntemdir.

Anahtar Kelimeler: Pilonidal sinüs hastalığı, Karydakis flep, Limberg flep, hayat kalitesi

Doi: $10.5578 /$ turkjsurg.4598 